\title{
The Union Between Gracilis and Sartorius Muscles in Leontopithecus: Morphofunctional Analysis
}

\author{
La Unión entre los Músculos Grácil y Sartorio \\ en Leontopithecus: Análisis Morfofuncional
}

"Marques, M. A.; ${ }^{* *}$ Vasconcellos, H. A. \& ${ }^{* * *}$ Azevedo, N. L.

\begin{abstract}
MARQUES, M. A.; VASCONCELLOS, H.A. \& AZEVEDO, N. L. The union betwen gracilis and sartorius muscles in Leontipithecus: Morphofunctional analisys. Int. J. Morphol., 24(2):215-220, 2006.

SUMMARY: The Golden Lion Tamarin (Leontopithecus rosalia) is an endemic primate of the Brazilian Atlantic coastal rainforest, still under serious extinction risk. Just a few is know about its anatomy, specifically the muscle unions. Due to the reasons exposed before, aiming understanding the locomotion of this and others primates, we decided to study the morphology and morphometry of the gracilis and sartorius muscles, and the relation between them, in three Leontopithecus species.
\end{abstract}

The current study examined 18 adult animal carcasses, of both sexes and with no physical abnormalities on the studied region. The material belongs to the Rio de Janeiro Primatology Center collection. The posterior members were dissected till the gracilis and sartorius muscles level, when were executed the morphometry, obtaining the cross section area and the histological analysis of the macroscopic between the gracilis muscle and the sartorius muscle.

We described the morphology of the gracilis muscle and sartorius muscle, obtained the average muscle morphometry values and studied, histologically, the union between these muscles.

The morphological and morphometric analysis allow us suggest descriptive parameters for these muscles the histological analysis allow us conclude the gracilis muscle and sartorius muscle fibers are not linked, but kept together by a conjunctive tissue, thus, being inserted into the medial side of the tibia. Functionally, we believe the gracilis muscle and the sartorius muscle shall contribute on the active containment of the knee joint and on the biomechanics of the posterior members, of these primates, known as runners.

KEY WORDS: Leontopithecus; Muscle union; Gracilis muscle; Sartorius muscle; Anatomy.

\section{INTRODUCTION}

It is needed to know the morphological conditions of all the animals, in special those under some extinction risk. The various Leontopithecus species are in this group, because we can't find in the specialized literature, enough data to allow us analyze diverse sectors functions of these animals anatomy.

There are references to several studies about skeletal muscles Tidball \& Quann, (1992); Yan et al. (1998); Yoshitake et al. (2002); Abmayr et al. (2003); Schwander et al. (2003), in members muscles, as on the chimpanzee Miller
(1952); and Alouatta (Grand, 1968). Schon (1968) studied posterior members muscles of the Alouatta. Marques et al. (1999) studied the Leontopithecus sartorius muscle.

Getty (1986) described a muscle union between the SM and GM in several animals: horse, cow, dog and cat, with no references to functional conditions.

In addition to the lack of descriptive data about the muscle union on the Leontopithecus, there is also no presence of hypotheses related to the isolated or joint action of these

* MS. Department of Anatomy, Estácio de Sá University, RJ - Brazil.

** MD, PhD. Department of Anatomy, State of Rio de Janeiro University and Medicine Faculty of Petrópolis, RJ - Brazil.

*** PhD. Department of Histology, State of Rio de Janeiro University - Brazil. 
muscles, in the general mobility and locomotion of these animals. These facts leaded us to study the morphology, macro and microscopic, of the muscle union found on the Leontopithecus.

\section{MATERIAL AND METHOD}

The studied samples numbered 18 carcasses, from adult animals, considering the presence of the molar teeth Hershkovitz (1977). Three Leontopithecus species were used: rosalia (Golden Lion Tamarin), chrysomelas (Golden Headed Lion Tamarin) and chrysopygus (Black Lion Tamarin), all captive bred, of both sexes and with no visual deformations, belonging to the Rio de Janeiro Primatology Center (CPRJ- FEEMA) collection.

The biometry of these animals was executed after death in order to obtain the measures and the data were recorded on a proper model. Afterwards, the animals were stored immerse in a formol solution (15\%), backwards down, with anterior and posterior members abducted and deflexed Coimbra-Filho, (1985) (Fig. 1).

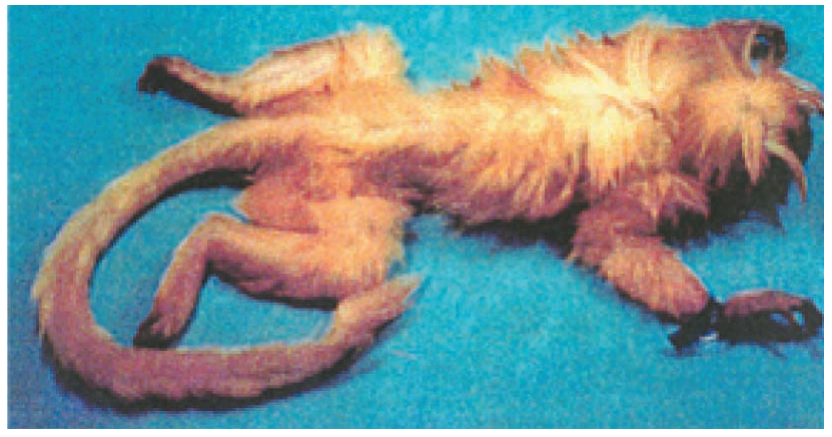

Fig. 1. Position of the animal for the dissection

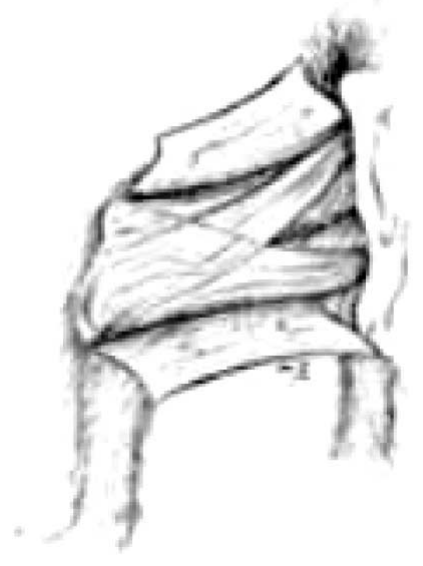

Fig. 2. Sartorius and gracilis muscles. The union of the muscles on the insertion.
After fixing the carcass in a table, in the position used for conservation, the dissection started with plans through a longitudinal and a anterior incision, at the medial portion of the thigh, and through two more transverse incisions: one at the anterior superior iliac spine level and another one at the tibia tuberosity. After fascia removal, the muscles were visualized and individualized (Fig. 2).

Muscle Morphometry: The muscle morphometry was achieved obtaining the following measures: $\mathrm{tl}$ - total length: the distance, in a straight line, from the origin to the insertion point; pw - proximal width: at the level of the $1 / 3$ superior portion of the origin tendon ( $1 \mathrm{~mm}$ underneath its fixation); mw - medium width: at the level of the medium $1 / 3$ of the muscle; dw - distal width: at the distal edge, before the macroscopic union between the muscles (Fig. 3).

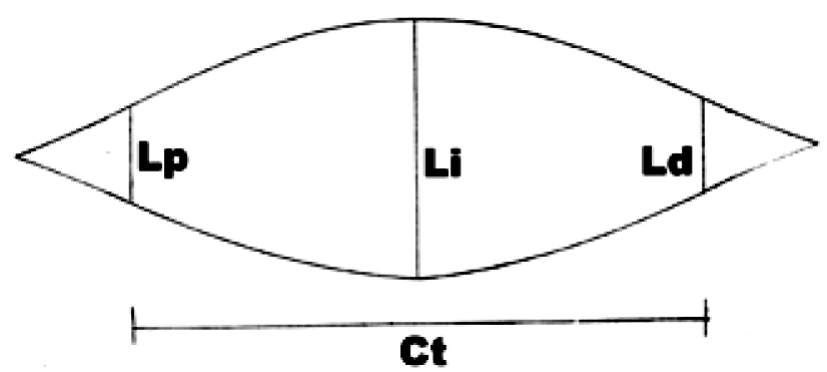

Fig. 3. Scheme about the morphometry of the muscles. Lp proximal width; $\mathrm{Li}$ - intermediate width; $\mathrm{Ld}$ - distal width; $\mathrm{Ct}$ total length.

Cross Section Area (CSA): The cross section area is a useful resource in calculating the possibility of muscle strength $(\mathrm{S})$ and work (W) development. An specially designed device, that allows a direct CA reading Santo Neto et al. (1984); Vasconcellos (1987); Marques (1995) is employed to obtain the CSA. After sectioning, the widest portion of the muscle is place inside the device and then, compressed, without being deformed, by the mobile part, thus the CSA value can be read (Fig. 4). All obtained data were recorded by its mean value, after 3 sequenced measures, on a proper model.

Fig. 4. Dispositive to measure the cross section área of the muscles.

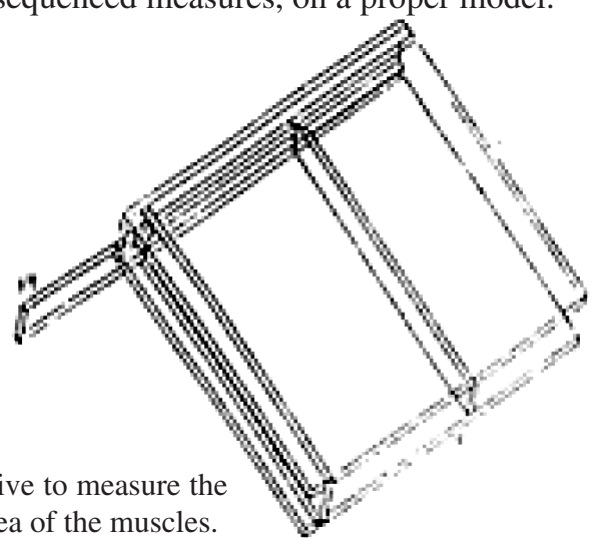


Histological Study: A small fragment of muscle tissue were taken, by a transversal cut, from the location where the GM and SM union can be macroscopically observed, for studying in optical microscopy, using hematoxilin-eosin coloration.

The lamina was made using by cutting off a fragment formolized at $10 \%$. All the specified times for the hematoxilin and eosin coloration technique (alcoholic solution at 70\%, and then at $90 \%$, following pure alcohol, each solution one hour long, with two repeated pure alcohol baths) were observed. Following, two xilol baths (one hour long each). We used paraffin, in two baths, one hour long each, for inclusion. After the microtomy, the laminas, were put on the stove/heather for 24 hours. The final stage was coloration, by hematoxilin-eosin.
Statistic study: The Microsoft ${ }^{\circledR}$ Excel (Windows $\mathrm{XP}(\mathbb{B})$ was used to calculate the muscle morphometry mean value.

\section{RESULTS}

Muscle Morphology Gracilis muscle (GM) - Located in the medial compartment of the thigh, maintaining the same width from the origin point until its union with the sartorius muscle. It belongs to the medial muscles group of the thigh. The origin is located in the pubic synphisis, presenting a few amounts of tendon fibers. The insertion is fixed in the superior third of the medial side of the tibia, through muscle fibers coated by a tough fascia. There were no morphological

Table I. Statistic results of the three studied species: M (muscle); FC (captive female); MC (captive male); SD (Standar desviation); Vhigh (maximum value); Vmin (minimum value); CV\% (variation coefficient); tl( total length); pw ( proximal width); mw (media width); dw (distal width)

\begin{tabular}{|c|c|c|c|c|c|c|c|c|c|c|c|c|c|c|c|c|c|c|}
\hline & Right $\mathrm{S}$ & Sartorius & muscle & & Right Sa & artorius & muscle & & Right & Iracilis $\mathrm{r}$ & uscle & & Left G & Tracilis $n$ & nuscle & & Ang D & Ang $\mathrm{E}$ \\
\hline & tl & pw & $\mathrm{mw}$ & $d w$ & $\mathrm{tl}$ & pw & $\mathrm{mw}$ & $d w$ & tl & pw & mw & $\mathrm{dw}$ & $\mathrm{tl}$ & pw & $\mathrm{mw}$ & $d w$ & & \\
\hline $847 \mathrm{FC}$ & 75,45 & 11,1 & 15,22 & 15,05 & 74,42 & 9,38 & 14,6 & 13,93 & 78,26 & 16 & 16,59 & 14,6 & 82,55 & 16,35 & 15,36 & 16,65 & 15 & 15 \\
\hline $848 \mathrm{FC}$ & 78,73 & 5,87 & 14,58 & 13,75 & 84,08 & 6,3 & 13,04 & 12,85 & 83,23 & 18,87 & 14,15 & 12,52 & 74,88 & 18,56 & 16,81 & 14,62 & 15 & 15 \\
\hline $928 \mathrm{FC}$ & 74,75 & 8,34 & 16,6 & 17,27 & 75,75 & 5,6 & 15,7 & 14,27 & 79,63 & 16,15 & 15,4 & 14,61 & 70,59 & 16,92 & 16,18 & 14 & 15 & 16,6 \\
\hline $1021 \mathrm{MC}$ & 10,5 & 0,43 & 0,85 & 0,7 & 9,93 & 0,63 & 1,19 & 0,82 & 9,16 & 0,95 & 1,07 & 0,96 & 8,47 & 1,16 & 1,02 & 1 & 15 & 15 \\
\hline $777 \mathrm{MC}$ & 74,53 & 8,93 & 14,84 & 16,48 & 83,45 & 7,92 & 14,81 & 13,5 & 77,47 & 14,26 & 13,27 & 13,08 & 84,48 & 11,68 & 12,95 & 13,17 & 15 & 15 \\
\hline $763 \mathrm{MC}$ & 73,81 & 6,07 & 12,45 & 12,86 & 77,61 & 7,69 & 11,16 & 11,24 & 83,48 & 14,18 & 13 & 11,88 & 77,22 & 15,42 & 12,37 & 12,21 & 15 & 15 \\
\hline$X$ & 64,63 & 6,79 & 12,42 & 12,69 & 67,54 & 6,25 & 11,75 & 11,10 & 68,54 & 13,40 & 12,25 & 11,28 & 66,37 & 13,35 & 12,45 & 11,94 & 15,00 & 15,27 \\
\hline SD & 26,57 & 3,67 & 5,83 & 6,10 & 28,50 & 3,06 & 5,42 & 5,15 & 29,20 & 6,33 & 5,64 & 5,17 & 28,81 & 6,40 & 5,87 & 5,57 & 0,00 & 0,65 \\
\hline $\mathrm{VC} \%$ & 41,12 & 54,06 & 46,89 & 48,06 & 42,20 & 48,86 & 46,09 & 46,38 & 42,60 & 47,26 & 46,04 & 45,87 & 43,41 & 47,92 & 47,16 & 46,61 & 0,00 & 4,28 \\
\hline Vhigh & 78,73 & 11,10 & 16,60 & 17,27 & 84,08 & 9,38 & 15,70 & 14,27 & 83,48 & 18,87 & 16,59 & 14,61 & 84,48 & 18,56 & 16,81 & 16,65 & 15,00 & 16,60 \\
\hline$V \min$ & 10,50 & 0,43 & 0,85 & 0,70 & 9,93 & 0,63 & 1,19 & 0,82 & 9,16 & 0,95 & 1,07 & 0,96 & 8,47 & 1,16 & 1,02 & 1,00 & 15,00 & 15,00 \\
\hline $821 \mathrm{FC}$ & 89,11 & 5,85 & 8,37 & 11,52 & 84,23 & 4,75 & 8,13 & 10,71 & 78,01 & 11,49 & 13,4 & 15,38 & 77,12 & 13,11 & 10,56 & 10,65 & 15 & 15 \\
\hline 794FC & 85,83 & 7,91 & 12,84 & 13,13 & 89,84 & 7,5 & 9,57 & 11,19 & 89,09 & 20,54 & 16,86 & 14,07 & 86 & 18,33 & 14,81 & 13,01 & 15 & 15 \\
\hline $1000 \mathrm{~F}$ & 83,01 & 5,75 & 7,42 & 9,89 & 75,12 & 7,99 & 8,89 & 9,62 & 88,63 & 13,87 & 13,4 & 12,33 & 82,39 & 14,47 & 16 & 15,3 & 15 & 15 \\
\hline $506 \mathrm{MC}$ & 80,6 & 8,83 & 11,05 & 10,93 & 89,53 & 8,54 & 13,22 & 12,84 & 86 & 13,49 & 13,2 & 11,33 & 88,14 & 12,66 & 12,85 & 13,99 & 15 & 15 \\
\hline $764 \mathrm{MC}$ & 84,31 & 4,96 & 7,89 & 9,38 & 81,65 & 7,28 & 8,07 & 10,27 & 81,99 & 13,94 & 11,88 & 12,33 & 78,88 & 13,39 & 12,22 & 12,8 & 15 & 15 \\
\hline $1011 \mathrm{MC}$ & 88,47 & 8,05 & 10,43 & 11,31 & 104,18 & 5,43 & 9,11 & 10,07 & 89,27 & 12,84 & 12,55 & 11,51 & 88,72 & 12,45 & 10,87 & 12,3 & 15 & 15 \\
\hline $\mathrm{X}$ & 85,22 & 6,89 & 9,67 & 11,03 & 87,43 & 6,92 & 9,50 & 10,78 & 85,50 & 14,36 & 13,55 & 12,83 & 83,54 & 14,07 & 12,89 & 13,01 & 15,00 & 15,00 \\
\hline SD & 3,26 & 1,57 & 2,12 & 1,32 & 9,86 & 1,49 & 1,91 & 1,14 & 4,59 & 3,16 & 1,73 & 1,58 & 4,86 & 2,20 & 2,16 & 1,57 & 0,00 & 0,00 \\
\hline $\mathrm{VC} \%$ & 3,82 & 22,72 & 21,92 & 12,00 & 11,28 & 21,61 & 20,14 & 10,59 & 5,37 & 22,00 & 12,75 & 12,34 & 5,82 & 15,67 & 16,76 & 12,07 & 0,00 & 0,00 \\
\hline Vhigh & 89,11 & 8,83 & 12,84 & 13,13 & 104,18 & 8,54 & 13,22 & 12,84 & 89,27 & 20,54 & 16,86 & 15,38 & 88,72 & 18,33 & 16,00 & 15,30 & 15,00 & 15,00 \\
\hline$V \min$ & 80,60 & 4,96 & 7,42 & 9,38 & 75,12 & 5,43 & 8,07 & 9,62 & 81,99 & 12,84 & 11,88 & 11,33 & 78,88 & 12,45 & 10,87 & 12,30 & 15,00 & 15,00 \\
\hline 969FC & 80,06 & 8,23 & 11,06 & 11,97 & 84,6 & 9,84 & 12,48 & 13,28 & 89,29 & 12,8 & 13,31 & 14,2 & 81,94 & 11,04 & 10,62 & 11,49 & 15 & 15 \\
\hline $916 \mathrm{FC}$ & 83,72 & 8,76 & 13,62 & 12,36 & 71,25 & 8,14 & 11,43 & 13,21 & 84,25 & 15,41 & 14,4 & 14,59 & 80 & 15,1 & 14,6 & 14 & 15 & 15 \\
\hline $1027 \mathrm{~F}$ & 9,2 & 0,42 & 1,16 & 1,13 & 8,5 & 0,72 & 1,24 & 1,32 & 8,36 & 1,76 & 1,59 & 1,43 & 8,04 & 1,72 & 1,65 & 1,34 & 15 & 15 \\
\hline $684 \mathrm{MC}$ & 83,49 & 7,9 & 13,04 & 14,5 & 74,83 & 5,87 & 14,05 & 14,25 & 82,32 & 17,22 & 17,9 & 15,97 & 80,16 & 17,63 & 18,26 & 17,13 & 15 & 15 \\
\hline $885 \mathrm{MC}$ & 94,43 & 9,01 & 12,16 & 11,61 & 91,34 & 9,58 & 10,07 & 12,46 & 88,9 & 17,7 & 15,68 & 12,14 & 89,98 & 17 & 17,99 & 18,24 & 15 & 15 \\
\hline $765 \mathrm{MC}$ & 88,92 & 8,27 & 12,79 & 14 & 92,04 & 5,72 & 9,5 & 12,07 & 89,17 & 13,35 & 13,52 & 13,67 & 88,98 & 11,85 & 12,63 & 12,8 & 15 & 15 \\
\hline$X$ & 73,30 & 7,10 & 10,64 & 10,93 & 70,43 & 6,65 & 9,80 & 11,10 & 73,72 & 13,04 & 12,73 & 12,00 & 71,52 & 12,39 & 12,63 & 12,50 & 15,00 & 15,00 \\
\hline SD & 31,80 & 3,30 & 4,72 & 4,94 & 31,50 & 3,39 & 4,50 & 4,85 & 32,15 & 5,87 & 5,71 & 5,33 & 31,40 & 5,87 & 6,15 & 6,04 & 0,00 & 0,00 \\
\hline $\mathrm{VC} \%$ & 43,39 & 46,43 & 44,41 & 45,16 & 44,72 & 51,09 & 45,96 & 43,69 & 43,61 & 45,00 & 44,88 & 44,39 & 43,91 & 47,34 & 48,69 & 48,30 & 0,00 & 0,00 \\
\hline Vhigh & 94,43 & 9,01 & 13,62 & 14,50 & 92,04 & 9,84 & 14,05 & 14,25 & 89,29 & 17,70 & 17,90 & 15,97 & 89,98 & 17,63 & 18,26 & 18,24 & 15,00 & 15,00 \\
\hline Vmin & 9,20 & 0,42 & 1,16 & 1,13 & 8,50 & 0,72 & 1,24 & 1,32 & 8,36 & 1,76 & 1,59 & 1,43 & 8,04 & 1,72 & 1,65 & 1,34 & 15,00 & 15,00 \\
\hline
\end{tabular}


differences considering sides and sexes. In two animals, the GM was linked to the long adductor muscle.

Sartorius muscle (SM) - A plain muscle, flat shaped, that crosses the thigh anterior and medial. In the origin point it is fixed to the anterior superior iliac spine, through a short and flat tendon and in the insertion point, through muscle fibers, in the proximal third of the medial side of the tibia body, with its fibers coated by a tough and linked to the GM.

Muscle Morphometry. The results for the muscle morphometry are in Tables I and II.

Table II. CSA (Cross section area result); S (strength); W (muscle work), from the 3 studied; M (muscle); R (right); L (left); PM (primatology museum).

\begin{tabular}{|c|c|c|c|c|c|c|c|c|c|c|c|c|}
\hline ANIMAL & Right & Sartorius & Muscle & Left & Sartorius & Muscle & Right & Gracilis & Muscle & Left & Gracilis & Muscle \\
\hline & $\mathrm{AT}$ & $\mathbf{F}$ & $\mathrm{T}$ & $\mathrm{AT}$ & $F$ & $\mathrm{~T}$ & $\mathrm{AT}$ & $\mathrm{F}$ & $\mathrm{T}$ & $\mathrm{AT}$ & $\mathrm{F}$ & $\mathrm{T}$ \\
\hline MP847 & 1.460 & 14.60 & 0.55 & 1.474 & 14.74 & 0.54 & 1.629 & 16.29 & 0.63 & 1.644 & 16.44 & 0.67 \\
\hline MP 848 & 1.465 & 14.65 & 0.57 & 1.342 & 13.42 & 0.56 & 1.785 & 17.85 & 0.74 & 0.230 & 23.00 & 0.86 \\
\hline MP928 & 1.343 & 13.43 & 0.50 & 1.202 & 12.02 & 0.45 & 1.520 & 15.20 & 0.60 & 1.787 & 17.87 & 0.63 \\
\hline MP1021 & 0.964 & 9.64 & 0.50 & 1.075 & 10.75 & 0.05 & 1.28 & 12.80 & 0.05 & 1.360 & 13.60 & 0.05 \\
\hline MP777 & 1.651 & 16.51 & 0.61 & 1.333 & 13.33 & 0.55 & 1.503 & 15.03 & 0.58 & 1.573 & 15.73 & 0.66 \\
\hline MP763 & 1.455 & 14.55 & 0.53 & 1.186 & 11.86 & 0.46 & 1.431 & 14.31 & 0.59 & 1.250 & 12.5 & 0.48 \\
\hline MP821 & 0.862 & 8.62 & 0.38 & 0.863 & 8.63 & 0.36 & 1.447 & 14.47 & 0.56 & 1.126 & 11.26 & 0.43 \\
\hline MP794 & 1.228 & 12.28 & 0.55 & 0.902 & 9.02 & 0.40 & 1.743 & 17.43 & 0.77 & 1.690 & 16.90 & 0.72 \\
\hline MP1000 & 0.588 & 5.88 & 0.24 & 0.752 & 7.52 & 0.28 & 1.317 & 13.17 & 0.58 & 1.378 & 13.78 & 0.56 \\
\hline MP506 & 1.011 & 10.11 & 0.40 & 1.084 & 10.84 & 0.48 & 1.389 & 13.89 & 0.59 & 1.552 & 15.52 & 0.68 \\
\hline MP764 & 0.708 & 7.08 & 0.29 & 1.026 & 10.26 & 0.41 & 1.191 & 11.91 & 0.48 & 1.109 & 11.09 & 0.43 \\
\hline MP1011 & 1.047 & 10.47 & 0.46 & 1.080 & 10.80 & 0.56 & 1.337 & 13.37 & 0.59 & 1.342 & 13.42 & 0.59 \\
\hline MP969 & 1.204 & 12.04 & 0.48 & 1.201 & 12.01 & 0.50 & 1.532 & 15.32 & 0.68 & 1.084 & 10.84 & 0.44 \\
\hline MP916 & 1.188 & 11.88 & 0.49 & 1.102 & 11.02 & 0.39 & 1.525 & 15.25 & 0.64 & 1.574 & 15.74 & 0.62 \\
\hline MP1027 & 1.055 & 10.55 & 0.04 & 1.156 & 11.56 & 0.04 & 1.722 & 17.22 & 0.07 & 1.655 & 16.55 & 0.06 \\
\hline MP684 & 1.323 & 13.23 & 0.55 & 1.349 & 13.49 & 0.50 & 1.927 & 19.27 & 0.79 & 1.912 & 19.12 & 0.76 \\
\hline MP885 & 1.032 & 10.32 & 0.48 & 1.020 & 10.20 & 0.46 & 1.633 & 16.33 & 0.72 & 1.802 & 18.02 & 0.81 \\
\hline MP765 & 1.224 & 12.24 & 0.54 & 1.003 & 10.03 & 0.46 & 1.337 & 13.37 & 0.59 & 1.421 & 14.21 & 0.63 \\
\hline
\end{tabular}

\section{DISCUSSION}

Muscle morphology. Beattie (1927) describes the musculature of the Callitrichix jacchus emphasizing that the SM does not have any relation with the GM.

Miller described the SM and GM in chimpanzees. The SM originates from the iliac anterior edge through a tendon arch, running at the surface, in the medial side of the thigh, being inserted over the superior third of the tibia, being involved by a aponeurotic sheath, linked to the gracilis and semitendinous muscles; the GM originates, in its main portion, in the inferior (lower) part of the pubis, merged to the short adductor muscle, and fixed in the antero-medial side of the tibia. According to this description, we can observe that there is similarity between these primates and the Leontopithecus.

Grand (1968) studied the GM and SM in the Alouatta emphasizing the link between them and the surrounding of both by an aponeurosis. Although the Alouatta them are classified as brachiators, they show runner characteristics, what should justify the muscle morphology, similar to the one found on the Leontopithecus.

In the musculature description of the Allouata, Schon (1968), tells the SM contributing in the as pes anserinus (Bursa anserinus) formation, being important in the animals locomotion, and also in helping the thigh flexion and abduction, and leg flexion. The GM is described showing, in the insertion point, only muscle fibers, what can also be observed in the Leontopithecus.

Getty studied the GM and SM of domestic animals. These muscles were found linked in the equine and in the bovine. The GM relates to the posterior muscles of the leg, 
being surrounded, together with these, by only one fascia. In dogs, the GM joins the SM from the origin to the insertion. In cats, both muscles are fixed by only one tendon to the insertion, this characteristic resembles the one found in Leontopithecus, although, cats do not show tendon fibers in this union. The locomotion of these animals is typically runners like, what also happen to the Leontopithecus.

The SM and GM description in humans shows that they are fixed by tendons in the medial side of the tibia tuberosity and that they are surrounded by a sheath aponeurotic, denominated as pes anserinus (bursa anserinus) Baptista Netto; Dangelo \& Fattini (2002), Moore (2001) and Didio (2002). In Leontopithecus, the fixation of these muscles can be observed in the same location, but through muscle fibers, and them, surrounded by a sheath aponeurotic. Baptista Neto emphasizes that the GM in the man executes the flexion and aduction of the thigh, what can also be observed in Leontopithecus, as this animal, in its habitat, maintains thighs and legs in flexion and adduction.

The SM, in Baptista Netto's (1944) description, shows fixation in the anterior superior iliac spine in the medial side of the tibia tuberosity, through an aponeurotic expansion that together with the gracilis and semitendinous muscles form the pes anserinus (bursa anserinus), not existing any kind of union between them. In Leontopithecus, this union is evident. The function of thigh flexioning executed by these muscles, in man, resembles to the observed in Leontopithecus.

Basmajian (1976) mentions the SM as a tibia medial rotator. In the Leontopithecus, whose topography in the thigh is similar to humans, we believe that the action of tibia medial rotation may also be done by these animals, due to its habitual posture.

Brunnstrom (1979) and Platzer (1988) mentions that, in humans, the muscles of thigh present tough unions with a fascia, or with an intermuscular tendon, or both. In our study, the SM and GM were found linked and involved by a fascia, in the insertion. Perhaps, this muscle union is used to enhance the action of the leg's flexion or to improve the muscle strength during the movements they are used. Similar unions can also be observed in the lombrical muscle of humans that reinforces the action of the finger's extensor muscle during interfalangical extension Basmajian (1976). It may also be observed in the action of the GM and SM of the Leontopithecus.

Bergman (1984) mentioned the GM fixation, in the leg's fascia, similar to the found in the Leontopithecus. These characteristics, in these animals, may allow the stabilization of this region.
While studying a black male corpse, Garbelotti (1999) identified a SM, biceps presenting a double origin, as it is observed in domestic animals. This sort of morphology was not observed in the Leontopithecus.

Muscle morphometry. The highest measure values of muscle morphometry were found in Leontopithecus rosalia females, what may suggest that, in this species and sex, there was a higher flexion potential. In Leontopithecus chrysomelas, a higher TL value was observed in males. In the females, the highest MW value was found in the right side. We found the highest TL values, for SM and GM, in the Leontopithecus chrysopygus males.

The VC\% in both PW sides of the three species, and, all the Leontopithecus chrysopygus items, presented high values, what shows great variation among the measures, preventing its use as a parameter. In the Leontopithecus chrysomelas, the DW presented a constant VC\%, what is due to the small variation of this measure, independent of sex.

The angle between the SM and GM did not present any alterations, what shows that the muscle disposition is the same in the three species.

The CSA and the muscle strength values were highest in the GM, especially in Leontopithecus chrysopygus females. The Leontopithecus rosalia presented the highest values in the left side of this muscle.

Comparing the CSA of the GM and SM in Leontopithecus with the results found by Brunnstrom (1979) in humans, it can be observed that these animals have low CSA values.

Dângelo \& Fattini states that the GM and SM are, respectively, inervated by the n obturatorius (L2, L3 and L4) and femoral nerves (L2, L3 and L4). This inervation is repeated in the Leontopithecus, what can be an indication of similar strengths or even a strength improvement.

Histological evaluation. According to what was evaluated, histologicaly, the GM and SM did not present union among muscle fibers, but were maintained, side by side, by conjunctive tissue tape, parallel until fixation. A clear separation between both muscles fibers is observed, and therefore, it can't be affirmed that there is muscle fusion, but a partial macroscopic union, probably allowing an improvement in muscle actions.

ACKNOWLEDGEMENTS: We greatefully acknowledge to the Rio de Janeiro Primatology Center (CPRJ-FEEMA) for the access to the studied animals carcasses collection. 
MARQUES, M. A.; VASCONCELLOS, H. A. \& AZEVEDO, N. L. La unión entre los músculos grácil y sartorio en Leontophitecus: Análisis morfofuncional. Int. J. Morphol., 24(2):215-220, 2006.

RESUMEN: El Tití León Dorado, (Leontopithecus rosalia) es un primate (especie de los Tamarinos y Titíes) de la foresta atlántica brasileña en serio riesgo de extinción. Poco se conoce acerca de su anatomía, específicamente de las uniones musculares. Debido a ello, con el objetivo de comprender la locomoción de éste y otros primates, estudiamos la morfología y morfometría de los músculos grácil y sartorio y la relación entre ellos, en 3 especies de Leontopithecus rosalia.

Se examinaron 18 animales adultos, de ambos sexos, sin anormalidades físicas en la región estudiada. El material pertenece a la colección del Centro de Primatología de Rio de Janeiro, Brasil. Los miembros posteriores fueron disecados hasta el nivel de los músculos grácil y sartorio, donde se efectuó la morfometría, obteniéndose, entre los músculos mencionados un área para su análisis histológico.

Describimos la morfología de los músculos grácil y sartorio. Se obtuvieron valores promedio de la morfometría muscular y se estudió histológicamente la unión entre esos músculos. El análisis morfológico y morfométrico permite sugerir parámetros descriptivos de esos músculos. El análisis histológico permite concluir que las fibras del músculo grácil y del músculo sartorio no están fusionadas sino que se mantienen juntas a través de tejido conjuntivo, así, se insertan en el lado medial de la tibia. Funcionalmente, creemos que los músculos grácil y sartorio contribuyen a una activa contención de la articulación de la rodilla y sobre la biomecánica de los miembros posteriores de esos primates, conocidos como corredores.

PALABRAS CLAVE: Leontopithecus; Unión muscular; Músculo grácil; Músculo sartorio; Anatomía.

\section{REFERENCES}

Abmayr, S. M.; Balagopalan, L.; Galletta, B. J.; Hong, S. J. Cell and molecular biology of myoblast fusion. Int. Rev. Cytol., 225:33-89, 2003.

Baptista Netto. Manual de dissecção. Rio de Janeiro, Editora Scientífica, 1944.

Basmajian, J. V. Electrofisiología de la acción muscular. Buenos Aires, Panamericana, 1976.

Beattie, J. The anatomy of the common marmoset (Hapale jacchus, Kuhl). Proc. Of the Zoo Soc. Of London, 3:665, 1927.

Bergman, R. A.; Thompson, S. A. \& Afif, A. K. Catalog of human variation. Baltimore, Urban \& Scharzenberg, 1984.

Brunnstrom, S. Clinical Kinesiology in Appendix A. Philadelphia, Davis, 1979.

Coimbra-Filho, A. F.; Pissinatti, A. \& Silva, R. R. O acervo do Museu de Primatologia (CPRJ-FEEMA). A Primatologia no Brasil 2. Anais $2^{\circ}$ Congresso. Brasileiro de Primatologia, 505-514, Campinas, 1985.

Dangelo, J. G. \& Fattini, C. A. Anatomia Humana Sistêmica e Segmentar. $2^{\mathrm{a}}$ ed. Rio de janeiro, Atheneu, 2002.

DiDio, L. J. A. Tratado de Anatomia Sistêmica Aplicada. $2^{\text {a }}$ ed. São Paulo, Atheneu, 2002. V. 1. pp. 266-7.

Garbelotti, J. S.; Rodrigues, C. F. S.; Nobeschi, L.; Seiji, F. \& Olave, E. Anatomical variation of the sartorius muscle. Rev. Chil. Anat., 17(1):95$7,1999$.

Getty, R. Anatomia dos Animais domésticos. $5^{\mathrm{a}}$ ed. Rio de Janeiro, Guanabara Koogan, 1986.

Grand, L. T. The functional Anatomy of the lower limbo f the Howler Monkey (Allouatta caraya). Am. J. Physical Anthropol., 28:163-82, 1968

Hershkovitz, P. Living New World Monkeys (Platyrrhni), Chicago Press, University of Chicago, 1977. V. 1.

Marques, M. A. Estudo morfológico e morfométrico dos músculos bíceps braquial, tríceps braquial e dorsoepitroclear em três espécies de Leontopithecus, 138f., ilustrada, Tese ( Mestrado em Morfologia), UERJ, Rio de Janeiro, 1995.
Marques, M. A. et al. Morphologic and Morphometric study in sartorius muscle in Leontopithecus, adults human and fetuses. Braz. J. Morphol. Science, 1, 1999.

Miller, R. The musculature of Pan Paniscus. Am. J. Anat. 91:183-232, 1952.

Moore, L. K.\& Dalley, A. F. Anatomia orientada para clínica. $4^{\mathrm{a}}$ ed.Rio de Janeiro, Guanabara Koogan, 2001.

Platzer, W. Atlas de Anatomia Humana com texto comentado e aplicações em clínica médica e cirúrgica. $5^{\text {a }}$ ed. Rio de Janeiro, Atheneu, 1988.

Santo Neto, H.; Carvalho, V. C. \& Penteado, C.V. Calculation of the force and work developed by the human abductor digiti minimi. Rev. Bras. Ciênc. Morfol. 1 (2): 9-11, 1984.

Schwander, M.; Leu, M. \& Stuman, M.Beta 1 integrins regulate myoblast fusion and sarcomere assetments. Dev. Cell, 4(5):675-85, 2003.

Schon, M. A. The muscular System of the Red Howling monkey. United Staes National Museum Bulletin Smithsonian. Institution Press Washington D.C., 1968.

Tidball, J. G. \& Quann, D. M. Reduction in myotendinous junction surface area of rats subjected to 4-day spaceflight. J. Appl. Physiol., 73 (1):5964, 1992.

Vasconcellos, H. A. O arco transverso anterior do pé humano: anátomofisiologia e contribuição da cabeça transversa (caput transversum) do m. adutor do hálux (m. adductor hallucis). Dissertação Mestrado, UERJ, 1987.

Yan, J.; Aizawa, Y.; Honma, S. \& Horiguchi, M. Re-evaluation of the human brachialis muscle by fiber analysis of supply nerves. Kaibogaku Zasshi, 73(3):247-58, 1998

Yoshitake, Y. \& Shinobara, M. Characteristics of surface mechanomyogram are dependent of the development of fusion of motor units in humans. J. Appl. Physiol., 93(5): 1744-52, 2002.

Correspondence to:

Dra. Mônica Marques Martins

Av. Tenete Coronel Muniz de Aragão № 898, Bl. 2 Apto. 502

Anil- Jacarepaguá

CEP 22765-005

Rio de Janeiro - $R$

Received. 14-12-2005

BRASIL 